\title{
Could canopy forests survive agricultural colonization in the Polabí lowland (Czech Republic)?
}

\author{
EVA BŘíZOVÁ \& LUCIE JUŘIČKOVÁ
}

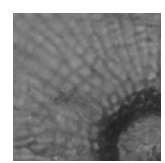

\begin{abstract}
The Polabí lowland is one of the most important agricultural areas in Central Europe. Since the Neolithic Age, agriculture has prevented full expansion of the mixed deciduous forest. We studied the succession of molluscan assemblages and/or fossil pollen in this area to answer the question as to how long the canopy forest could survive ongoing human impact. Environments suitable for the fossilization of these two fossil types differ, and the joint occurrence of both is rare. However, the $0.75 \mathrm{~m}$ deep profile of alluvial loams and clays situated in the irregularly inundated floodplain area of the Dubanka stream yielded material rich in both mollusc shells and pollen. Very rich molluscan assemblages occur only in a $45 \mathrm{~cm}$ thick layer, which was dated using the AMS radiocarbon method to the Bronze Age (1796 BC-1258 BC). The molluscan assemblages consist of continuously occurring rare deciduous woodland species (such as Discus perspectivus, Platyla polita, Cochlodina orthostoma, Ruthenica filograna) and species of relict wetlands (e.g. Perpolita petronella, Vertigo angustior, V. antivertigo, Vallonia enniensis). Pollen analyses also suggest the presence of wetland assemblages, with a huge proportion of alder in the central part of the succession followed by willow. The deciduous forests consist of elm (Ulmus), oak (Quercus), lime tree (Tilia), maple (Acer) and hazel (Corylus). Pollen grains of spruce (Picea), white fir (Abies) and beech (Fagus) confirm the late Holocene age of the profile. These results provide evidence of a woodland and wetland mosaic which still covered this landscape during the Bronze Age, in contrast with the present-day monotonous open lowland. $\bullet$ Key words: canopy forest, Bronze Age, agriculture landscape, mollusc succession, pollen analyses, Holocene.
\end{abstract}

BŘíZOVÁ, E. \& JUŘIČKOVÁ, L. 2011. Could canopy forests survive agricultural colonization in the Polabí lowland (Czech Republic)? Bulletin of Geosciences 86(2), 283-300 (6 figures, 5 tables). Czech Geological Survey, Prague. ISSN 1214-1119. Manuscript received February 22, 2011; accepted in revised form April 20, 2011; published online June 10, 2011; issued June 20, 2011.

Eva Bř́zová, Czech Geological Survey, Klárov 3/131, 11821 Prague 1, Czech Republic; eva.brizova@geology.cz• Lucie Juřičková, Department of Zoology, Faculty of Science, Charles University in Prague, Viničná 7, CZ-128 44 Prague 2, Czech Republic; lucie.jurickova@seznam.cz

A river floodplain is a very specific ecosystem of great importance in the landscape. The majority of authors accept the floodplain (alluvium) as consisting of soils or river sediments lining an area impacted by floods and built up by river erosion, relocation and accumulation over time. Broad rivers produce an alluvial terrace system affecting the whole character of the landscape, while deposits accumulated by small rivers affect only the local habitats. However, both cause an increase in the diversity of the abiotic environment and associated organisms (Kalicki 2006; Břízová 2007, 2008a; Jankovská 2008). The development of floodplains during the last few centuries can be described based on written sources or pictures of a particular landscape. The geology and geomorphology of river sediments provide information on millenniums of landscape history (e.g. Boothroyd \& Nummendal 1978; Břízová \& Havlíček 2000; Břízová et al. 2000, 2001, 2007; Tyráček 2001; Bridge 2003; Bridgland \& Westaway 2007; Adamová et al. 2008; Hradecká et al. 2008; Brown et al. 2009). In suitable sedimentation environments (Břízová 1999a, Ložek 2003, Pišút et al. 2010), plant remains and pollen can supplement information on floodplain succession and enable dating in the order of centuries. It is only rarely that information on fossil mollusc shells can be added to this complex of knowledge because the fossilization conditions for pollen and molluscs are quite different (Ložek 2000, 2007). Previously, there had been only three known sites with a parallel occurrence of molluscan shells and pollen in Holocene sediments - Kobeřice (Kovanda 1987, Břízová 1994), Rynholec (Kovanda 1993, Břízová 1999b) and Dudváh (Pišút et al. 2010). The process of sediment accumulation by a river is repeatedly interrupted by river erosion (Dreslerová et al. 1994, Břizová 2001). Fluvial processes during the Late Glacial and Holocene depended largely on climatic conditions. Human activity, especially deforestation and agriculture, have further affected these processes since 

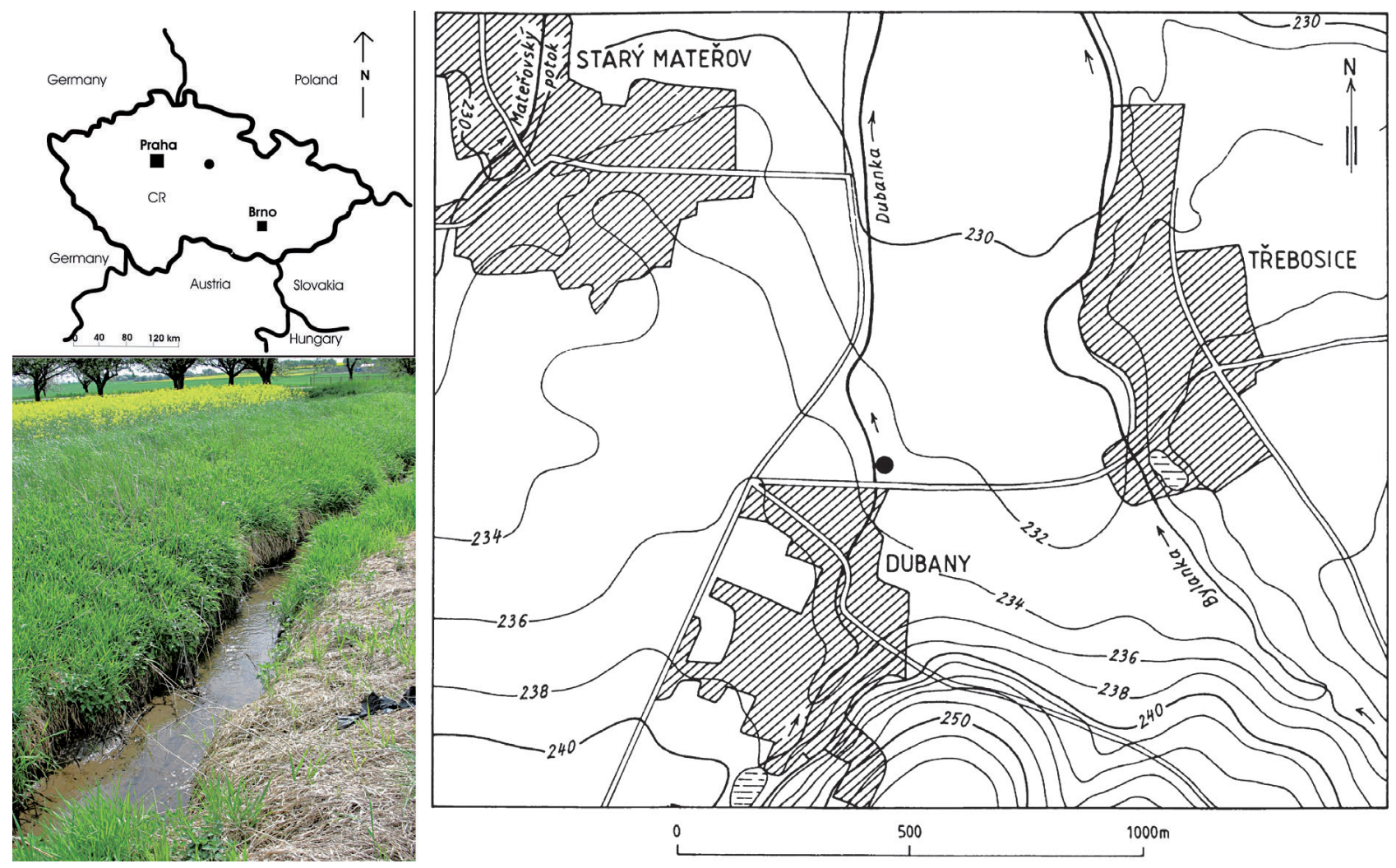

Figure 1. Location of the Dubany site and the present state.

Table 1. AMS radiocarbon age dating of the molluscan successions in Dubany.

\begin{tabular}{lllccc}
\hline Sample name & Laboratory code & Material & Depth $(\mathrm{m})$ & Conv. Age \pm Err. yr BP ${ }^{14} \mathrm{C}$ & Calib. Age y.BC ${ }^{14} \mathrm{C}(95.4 \%$ probability) \\
\hline Dubany MF 3 & Poz-33200 & shell & $0.15-0.25$ & $3,030 \pm 40$ & $1,408-1,132$ \\
Dubany MF 5 & UGAMS 6450 & shell & $0.40-0.45$ & $3,430 \pm 30$ & $1,877-1,639$ \\
\hline
\end{tabular}

the Neolithic Age (Kalicki 2006, Brown 2009). One of the most important areas of Neolithic settlement in Central Europe is the Polabí lowland. Many data indicate that the Polabí lowland has had an open landscape without canopy forest since the Neolithic Age (Dreslerová et al. 2004, Ložek 2007). However, there are important differences between the drier western part and more humid eastern part of this area where only Bronze Age settlements have been recorded (Pleiner et al. 1978, Ložek 2007). While fully developed forest molluscan fauna are recorded as not occurring in the western part, we have only scattered information on the eastern Polabí lowland which is very important biogeographically. The presence of canopy forests in the eastern Polabí is important in the light of connectivity of Central Bohemian woodland communities with the hilly surroundings which were much later impacted by agriculture. Moreover, the eastern Polabí adjoins an area from which Carpathian forest species may have potentially spread to the west.

Some very old data are available from this area (Babor 1901; Frankenberger 1913; Petrbok 1916, 1951; Hlaváč
1937), all of which either commented on or revised the fossil material of previously woodland molluscs (including Discus perspectivus and Macrogastra tumida) collected by J. Koštál in Jesničánky near Pardubice. Unfortunately, this material lacked a stratigraphic context and has been lost. However, it indicated the occurrence of woodland, wetland and freshwater snail species in Holocene sediments of an uncertain age. Kovanda (1971) characterized this site as a flat deposit of palustric limestones (alms, marls and calcareous fens). Another nearby site at Staré Jesenčany is built up of deposits of calcareous fens, fine grained tufas and alms (Kovanda 1971). Some wetland and woodland snail species of uncertain age (Discus perspectivus, Cochlodina orthostoma, Vertigo moulinsiana) have also been detected at this site (Hlaváč 1937, 1956; Volšan 1969). Unfortunately, both of these sites have been destroyed. These scattered historical data, though, give some indications of the presence of canopy forest snail species in some sites of the eastern Polabí lowland during the Holocene past. Thus, the discovery of 
Figure 2. Malacospectra MSS of the Dubanka stream floodplain. The percentage frequency mollusc diagram expresses the relative proportions of species (MSS malacospectra) in individual layers. Ecological groups were used according to Ložek (1964) and Alexandrowitz (1987)

woodland species in general woodland/open country species open-ground species in general marsh and aquatic species

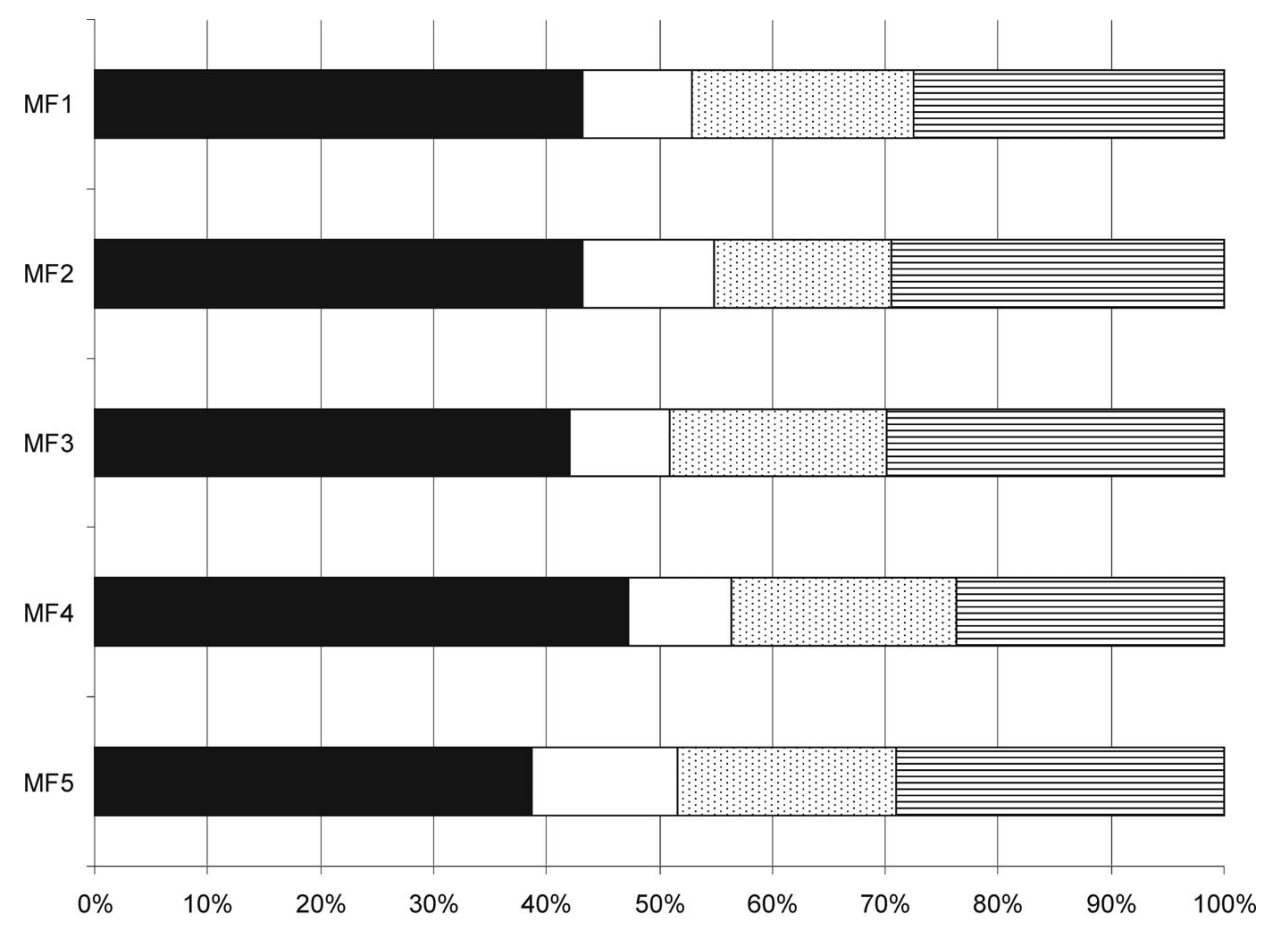

a site suitable for paleoecological research in this area was of great interest. Here we focus on the following questions: How old are the woodland snail species from the river floodplain of this prehistoric area? How long could the canopy forest survive human impacts? What was the appearence of this landscape in the past?

\section{Material and methods}

\section{Description of the site}

The Dubany site was discovered by J. Straka during Quaternary mapping in 1985 . The profile was uncovered as tens-of-meters long outcrops on the right bank of the Du-

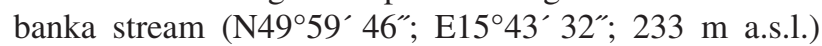
southwest of the town of Pardubice (see Fig. 1). The various types of fluvial sediments had built up a complex of river accumulations on the younger terrace of the nearby Chrudimka river. Part of the flood loams is calcium rich with numerous floated tufa incrustations which offer suitable conditions for the fossilization of mollusc shells, and these layers $(0.45 \mathrm{~m})$ contain huge numbers of these shells. Calcareous sediments in a floodplain always indicate low river activity (Kovanda 1983). The complex of sediments with an abundance malacofauna thus documents relatively quiet river overbank sedimentation, probably in an irregularly inundated floodplain.

The profile under the sterile $0.5-1 \mathrm{~m}$ thick layer of floodplain loams was sampled to produce 5 malacological and 16 palynological samples, as described below.

\section{Lithology}

Lithology of the profile and location of the samples for mollusc fauna (MF) analyses:

$0-0.10 \mathrm{~m}$ dark grey clay loam with poorly scattered tufa incrustations, rusty spotted in the middle - MF 1

$0.10-0.15 \mathrm{~m}$ the same but darker and more humic-MF 2

$0.15-0.25 \mathrm{~m}$ the same but with numerous tufa incrustations (floated tufa) - MF 3

$0.25-0.40 \mathrm{~m}$ very dark grey humic loams with numerous small, rough tufa incrustations (floated tufa) $-\mathrm{MF} 4$

0.40-0.45 m grey-black highly humic clay loams with scattered tufa incrustations - MF 5

$0.45-0.55 \mathrm{~m}$ dark grey and rusty spotted clays - layer malacologically sterile

$0.55-0.75 \mathrm{~m}$ grey poorly spotted clay loams - layer malacologically sterile.

\section{Molluscan samples}

The molluscan successions were sampled using the standard methods (Ložek 1964) - $5 \mathrm{dm}^{3}$ samples of sediment were taken from all macroscopically distinguishable layers (see lithology) throughout the profile. Molluscan shells were extracted from the sediments by a combination of floating and sieving. After careful drying, each sample was disaggregated in water. Floating snails were repeatedly decanted into a $0.5 \mathrm{~mm}$ sieve and dried under laboratory 
Table 2. Assemblages of molluscs in individual layers of the Dubanka stream floodplain sediments. For layer number, see above. Ecological characteristics: General ecological groups: A - woodland (in general); B - open country; C - woodland/open country; D - water, wetland. Ecological groups: 1 - woodland (sensu stricto); 2 - woodland, partly semi-opened habitats; 3 - damp woodland; 4 - xeric open habitat; 5 - open habitats in general (moist meadows to steppes). Woodland/open country: 6 - predominantly dry; 7 - mesic or various; 8 - predominantly damp; 9 - wetlands, banks; 10 - aquatic habitats. Biostratigraphic characteristics: + - loess species, (+) - local or ocasional loess species, ! - species characteristic of warm phases, (!) - eurythermic species of warm phases, !! - index species of warm phases, G - species surviving the Glacial out of loess zone, (G) - ditto as relics, $\mathrm{M}$ - modern immigrants (late Holocene index species). Presence in layers: $\mathrm{R}$ - rare (1-3 individuals); $\mathrm{O}$ - occasional (4-10 individuals); $\mathrm{C}-\mathrm{common}$ (10-25 individuals); D - dominant (more than 75 individuals).

\begin{tabular}{|c|c|c|c|c|c|c|c|c|}
\hline \multirow{2}{*}{\multicolumn{2}{|c|}{ Ecological group }} & \multirow{2}{*}{ Biostratigraphy } & \multirow{2}{*}{ List of species } & \multicolumn{5}{|c|}{ Layer } \\
\hline & & & & 1 & 2 & 3 & 4 & 5 \\
\hline \multirow{27}{*}{ A } & \multirow{15}{*}{1} & $!$ & Acanthinula aculeata & & $\mathrm{R}$ & $\mathrm{R}$ & $\mathrm{O}$ & \\
\hline & & $!$ & Aegopinella pura & $\mathrm{R}$ & $(\mathrm{R})$ & $\mathrm{R}$ & $\mathrm{R}$ & \\
\hline & & $!$ & Cochlodina laminata & $\mathrm{C}$ & $\mathrm{R}$ & $\mathrm{O}$ & $\mathrm{C}$ & $\mathrm{R}$ \\
\hline & & $!$ & Cochlodina orthostoma & & & $\mathrm{R}$ & & \\
\hline & & $! !$ & Discus perspectivus & $\mathrm{R}$ & $\mathrm{R}$ & $\mathrm{R}$ & $(\mathrm{R})$ & \\
\hline & & (G) & Discus ruderatus & $\mathrm{R}$ & $\mathrm{R}$ & $\mathrm{R}$ & $\mathrm{R}$ & \\
\hline & & $!$ & Ena montana & & & $(\mathrm{R})$ & $\mathrm{R}$ & (R) \\
\hline & & $!$ & Isognomostoma isognomostomos & $\mathrm{C}$ & $\mathrm{R}$ & $\mathrm{C}$ & $\mathrm{R}$ & $\mathrm{R}$ \\
\hline & & $!$ & Macrogastra plicatula & $\mathrm{C}$ & $\mathrm{R}$ & $\mathrm{O}$ & $\mathrm{R}$ & \\
\hline & & (MS) & Monachoides incarnatus & $\mathrm{O}$ & A & $\mathrm{O}$ & $\mathrm{C}$ & $\mathrm{R}$ \\
\hline & & $!$ & Petasina unidentata & $\mathrm{O}$ & $\mathrm{R}$ & $\mathrm{R}$ & $\mathrm{O}$ & \\
\hline & & $!$ & Platyla polita & $\mathrm{C}$ & $\mathrm{C}$ & $\mathrm{C}$ & $\mathrm{C}$ & $\mathrm{R}$ \\
\hline & & $!$ & Ruthenica filograna & & $\mathrm{R}$ & $\mathrm{R}$ & $\mathrm{R}$ & \\
\hline & & $!$ & Semilimax semilimax & $\mathrm{O}$ & $\mathrm{O}$ & $\mathrm{R}$ & $\mathrm{O}$ & \\
\hline & & $(!)$ & Vertigo pusilla & $\mathrm{R}$ & $\mathrm{R}$ & & $\mathrm{O}$ & \\
\hline & \multirow{9}{*}{2} & $!$ & Aegopinella $\mathrm{cf}$. minor & $\mathrm{O}$ & $\mathrm{O}$ & $(\mathrm{R})$ & $\mathrm{C}$ & $\mathrm{R}$ \\
\hline & & $!$ & Alinda biplicata & $\mathrm{C}$ & $\mathrm{O}$ & $\mathrm{C}$ & $\mathrm{O}$ & (R) \\
\hline & & $(+)$ & Arianta arbustorum & $\mathrm{O}$ & $\mathrm{O}$ & $\mathrm{R}$ & $\mathrm{C}$ & $\mathrm{R}$ \\
\hline & & $!$ & Cepaea hortensis & $\mathrm{C}$ & $\mathrm{C}$ & $\mathrm{R}$ & $\mathrm{R}$ & $\mathrm{R}$ \\
\hline & & $!$ & cf. Helix pomatia & & & & $\mathrm{R}$ & \\
\hline & & $!$ & Discus rotundatus & A & $\mathrm{A}$ & $\mathrm{C}$ & $\mathrm{C}$ & $\mathrm{O}$ \\
\hline & & (G) & Eucobresia diaphana & $\mathrm{R}$ & & $\mathrm{R}$ & $\mathrm{R}$ & \\
\hline & & $(!)$ & Fruticicola fruticum & $\mathrm{O}$ & $\mathrm{O}$ & $(\mathrm{R})$ & $\mathrm{R}$ & \\
\hline & & $(+)$ & Vitrea crystallina & A & $\mathrm{O}$ & $\mathrm{C}$ & $\mathrm{O}$ & $\mathrm{R}$ \\
\hline & \multirow{3}{*}{3} & (G) & Clausilia pumila & $(\mathrm{R})$ & & & $\mathrm{R}$ & $\mathrm{R}$ \\
\hline & & $!$ & Macrogastra ventricosa & $\mathrm{O}$ & $\mathrm{R}$ & $\mathrm{R}$ & $\mathrm{R}$ & \\
\hline & & G & Perforatella bidentata & $\mathrm{C}$ & $\mathrm{R}$ & $(\mathrm{R})$ & $\mathrm{R}$ & \\
\hline \multirow{6}{*}{ B } & 4 & M & Cecilioides acicula & A & $\mathrm{C}$ & A & $\mathrm{C}$ & $\mathrm{O}$ \\
\hline & \multirow{5}{*}{5} & + & Pupilla muscorum & $\mathrm{O}$ & $\mathrm{O}$ & $\mathrm{C}$ & $\mathrm{R}$ & $\mathrm{R}$ \\
\hline & & $(!)$ & Truncatellina cylindrica & & $\mathrm{R}$ & & & \\
\hline & & $(+)$ & Vallonia costata & A & A & A & $\mathrm{C}$ & $\mathrm{R}$ \\
\hline & & G & Vallonia pulchella & A & $\mathrm{D}$ & A & $\mathrm{C}$ & $\mathrm{R}$ \\
\hline & & (G) & Vertigo pygmaea & $\mathrm{R}$ & $\mathrm{R}$ & $\mathrm{O}$ & $\mathrm{O}$ & \\
\hline \multirow{6}{*}{$\mathrm{C}$} & \multirow{6}{*}{7} & $(+)$ & Clausilia parvula & & & & $\mathrm{R}$ & \\
\hline & & $(+)$ & Cochlicopa lubrica & $\mathrm{C}$ & A & A & $\mathrm{R}$ & $\mathrm{O}$ \\
\hline & & (G) & Euconulus cf. praticola & $\mathrm{R}$ & & & & \\
\hline & & $(+)$ & Euconulus fulvus & & $\mathrm{R}$ & & $\mathrm{R}$ & \\
\hline & & & Limacidae/Agriolimacidae & $\mathrm{O}$ & $\mathrm{O}$ & $\mathrm{R}$ & & \\
\hline & & $(+)$ & Perpolita hammonis & A & $\mathrm{C}$ & $\mathrm{C}$ & $\mathrm{O}$ & \\
\hline
\end{tabular}


Table 2. continued

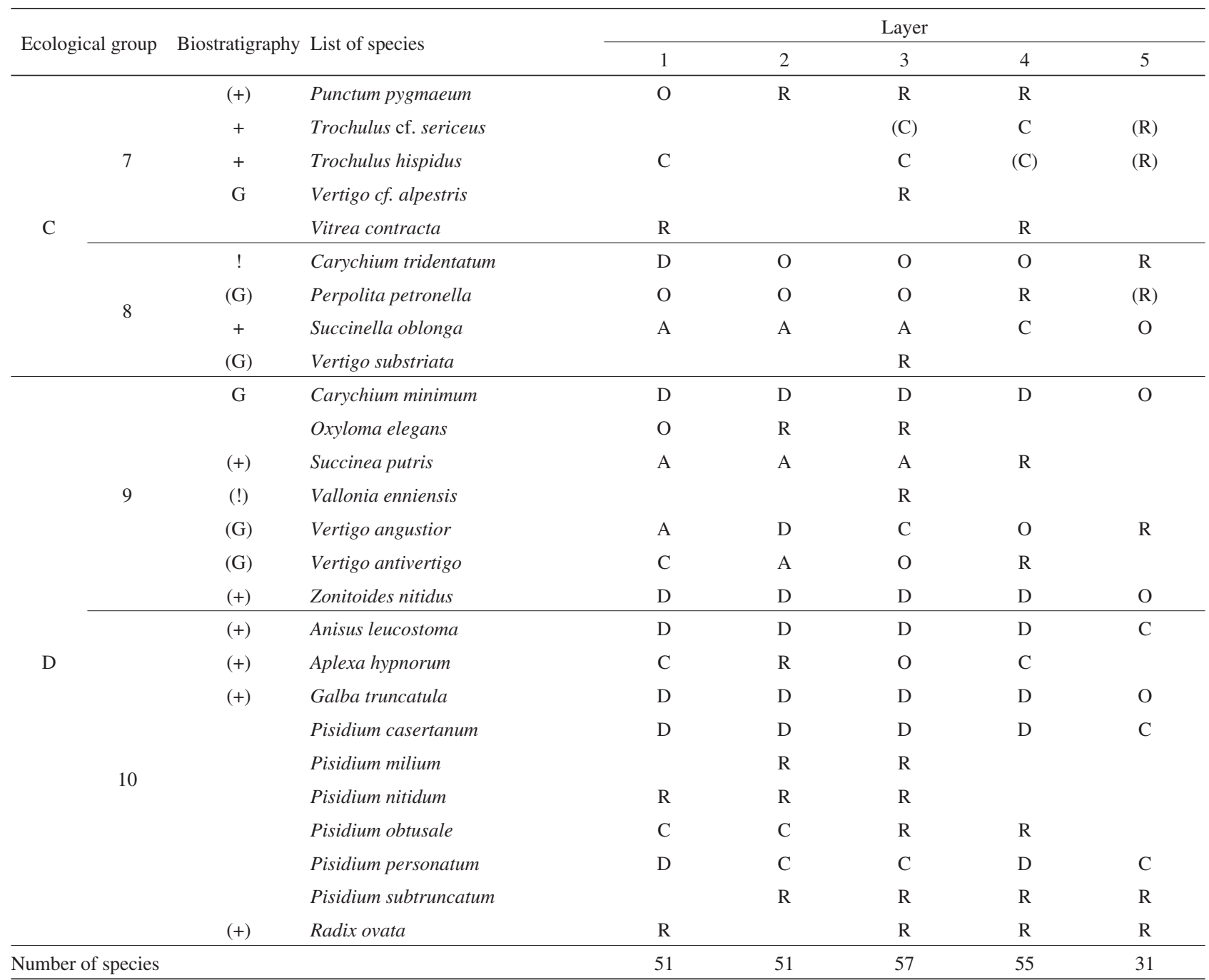

conditions. The sediment was then sorted by sieving, shells were systematically removed from the sediment fractions, followed by drying and examination under a binocular microscope.

A percentage frequency mollusc diagram was created expressing the relative proportions of species (MSS malacospectra) in the separate layers. Ecological groups were defined according to Ložek (1964) and Alexandrowitz (1987).

\section{Pollen samples}

Pollen was sampled at regular intervals - 16 samples at $5 \mathrm{~cm}$ distances over the entire $0.75 \mathrm{~m}$ deep profile. After one day of maceration in hydrofluoric acid (Overbeck 1958), Erdman's (1943, 1954) modified method was used. Maceration in HF serves to decompose of inorganic particles (Overbeck 1958, Faegri \& Iversen 1964), the acetolysis method was used to decompose cellulose and surplus orga- nic remains which prevent clear observation and calculation of palynological objects. Glycerin with ethyl alcohol and distilled water were used as the mounting medium. Mounts were observed and counted under the microscope. For the pollen diagram, the sum of wood (AP) and herb (NAP) pollen grains was set as $100 \%$. Based on this sum, absolute values of wood and herb pollen grains were recalculated (Table 5). There were approximately 500 pollen grains in a single sample. A pollen diagram was constructed based on these relative values using the software POLPAL (Walanus \& Nalepka 1999). Spores and the remains of other organisms were not counted, but noted. Relative dating of the pollen spectrum was estimated, and a reconstruction of the vegetation succession was produced using Firbas' (1949, 1952) division, modified by Mangerud (Walanus \& Nalepka 2010). The taxonomical classification of pollen follows Hejný \& Slavík (1988-1992), Slavík (1995-2000), Kubát et al. (2004), Slavík \& Štěpánková (2004) and Štěpánková et al. (2010). 


\section{Dating}

Radiocarbon data analyses were performed in the Poznań Radiocarbon Laboratory, Poland, and the Centre for Applied Isotope Studies at the University of Georgia, USA. Mollusc shells were measured by the AMS (Accelerator Mass Spectrometry) method and calibrated for variable initial ${ }^{14} \mathrm{C}$ concentration using the $\mathrm{OxCal} v 4.1$ calibration program (Bronk Ramsey 2009, see Table 1).

\section{Results}

\section{Molluscan analyses}

Table 2 shows the molluscan assemblages in the separate layers. Altogether, 65 species were recorded in five layers (MF1-MF5). Species of all ecological groups (sensu Ložek 1964, Alexandrowitz 1987) were found except for woodland/open country species of predominantly dry habitats (group 6). Twenty-seven woodland species represent $42 \%$ of the total molluscan species diversity. The more important rare woodland species are Discus perspectivus, Platyla polita, Acanthinula aculeata, Cochlodina orthostoma, Macrogastra plicatula, Ruthenica filograna, Ena montana, Aegopinella pura, Petasina unidentata and Isognomostoma isognomostomos. All these species indicate a fully developed canopy forest. In the youngest layer (MF1) there is a mosaic of woodland, woodland/open country and open country species with species of wetland and stagnant water. A similar mosaic occurs throughout the whole succession. However, the main habitat type in this site was forest, and other non-woodland species characterize the habitat diversity of nearby surroundings. Both the maximum number of woodland species, including the most rare (Cochlodina orthostoma, Ruthenica filograna), and the maximum species diversity (57 species) occur in MF 3, dated to the early Bronze Age. The minimum species diversity in MF 5 could have been affected by poorer fossilization conditions (Fig. 2).

\section{Pollen analyses}

The most important pollen grains and the pollen diagram are shown in Figs 3-6 and Table 5.

Comments on the pollen diagram follow:

LPAZ (local pollen assemblage zone):

\section{D1-IV: Pinus - Betula - Juniperus - Poaceae - Apiaceae - Artemisia - (Dinoflagellata)}

depth $0.55-0.75 \mathrm{~m}$

The situation in this basal layer was complicated both stratigraphically and vegetationally. Preboreal flora and re-deposition of Dinoflagellata from the Cretaceous bedrock was observed. This re-deposition was caused by the parallel erosion of Cretaceous sediments and accumulation of Holocene grey clays. The dominance of Poaceae, Cyperaceae, Alisma, Sparganium/Typha angustifolia and Polypodiaceae is indicative of slowly overgrowing river banks and wetlands. Pioneer woods with Scots pine (Pinus) and birch (Betula) appear in this layer. Pollen grains of Apiaceae, Artemisia and a low content of wood pollen grains $(\mathrm{AP}<50 \%)$ also indicate an open landscape.

\section{D2-V: Betula - Corylus - Cyperaceae - Poaceae - Rumex}

depth $0.50-0.55 \mathrm{~m}$

A very thin layer of probably Boreal sediments. The loam clays were sediments from a wetland environment (Cyperaceae, Poaceae). The wood component markedly decreased - birch dominated, whereas pine disappeared. The first more extensive occurrence of alder was dated to this period.

\section{D3-VI-VIII: Alnus - Salix - Asteraceae Liguliflorae}

depth $0.45-0.50 \mathrm{~m}$

The vegetation implies sedimentation during some of the Atlantic climatic periods (VI-VII). Wetland vegetation with alder and willow probably occurred around the river. The first thermophilous trees appeared (Ulmus, Quercus, Tilia, Acer). The herb vegetation is relatively poor except for some Asteraceae (mainly Liguliflorae).

\section{D4-VII-VIII: Alnus - Quercetum mixtum - (Polypodiaceae)}

depth $0.40-0.45 \mathrm{~m}$

An expansion of alder, with a humid climate supporting the occurrence of Polypodiaceae. The thermophilous trees

Figure 3. Palynomorphs from Dubany profile D - AP. • A, B - Pinus, depth 0.05, $0.10 \mathrm{~m} . \bullet \mathrm{C}, \mathrm{D}-$ Juniperus, depth $0.10 \mathrm{~m}$. $・$ E-I - Salix, depth 0.10 , $0.05 \mathrm{~m}$. $\bullet \mathrm{J}-\mathrm{L}-$ Betula, depth 0.05, $0.10 \mathrm{~m}$. $\bullet \mathrm{M}, \mathrm{N}-$ Corylus, depth $0.75 \mathrm{~m}$. NAP. $\bullet \mathrm{O}, \mathrm{P}-$ Cerealia T. Triticum, depth $0.75 \mathrm{~m}$. $\bullet$ Q-T - Poaceae, depth 0.05 , $0.10 \mathrm{~m}$. $\bullet \mathrm{U}, \mathrm{V}-$ Iris-type, depth $0.10 \mathrm{~m}$. Scale $10 \mu \mathrm{m}$. Photo E. Bř́zová. 
Eva Bř́zová \& Lucie Juřičková • Could canopy forests survive agricultural colonization in the Polabí lowland
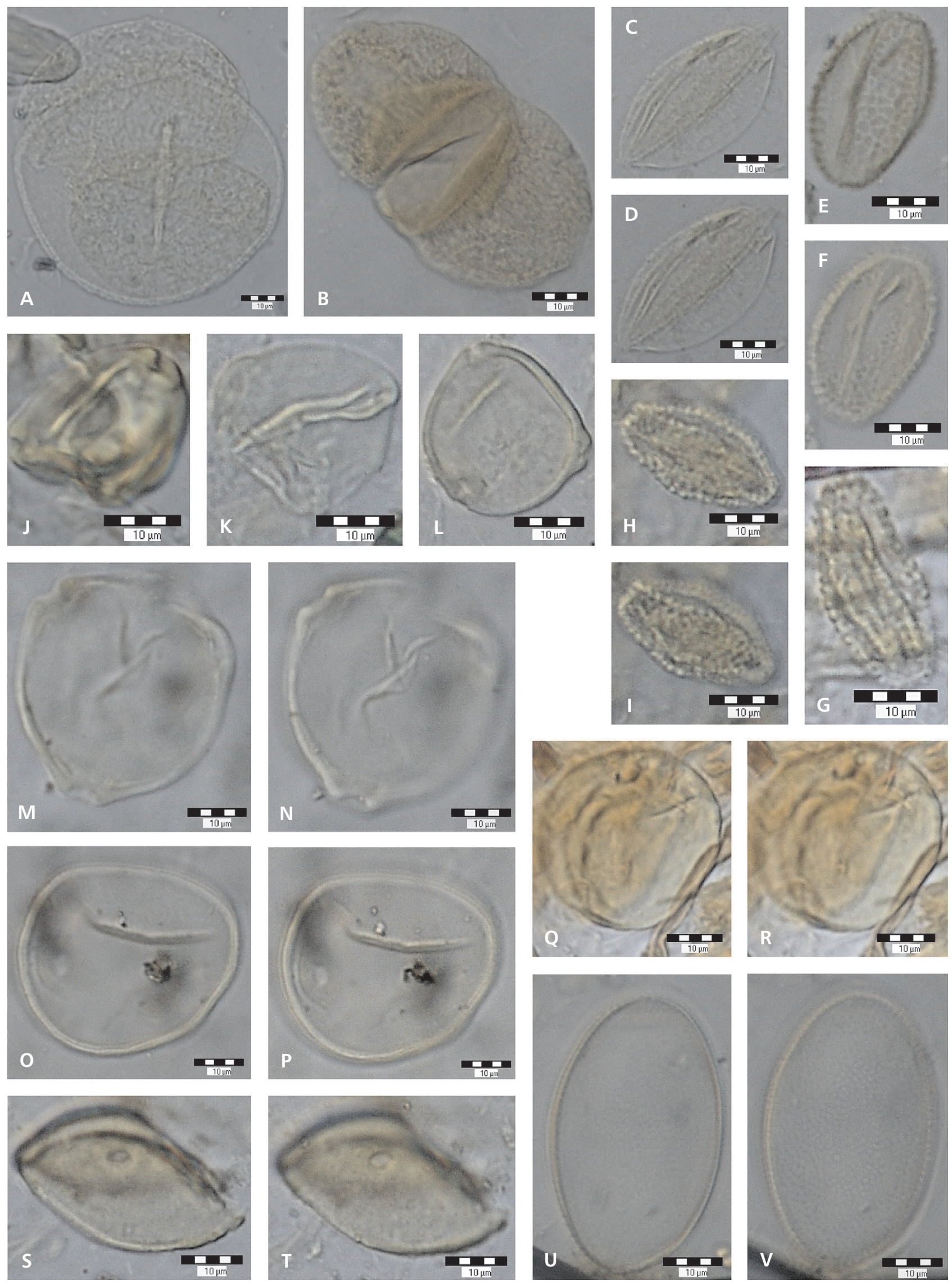
(Ulmus, Quercus, Tilia) continue to occur. Probably also an Atlantic (VII) period.

\section{D5-VIII: Alnus - Corylus - Tilia}

depth $0.25-0.40 \mathrm{~m}$

Alder continues to occur along with open water wetlands (maximal increase of Potamogeton). Other herbs were also noted, e.g. Brassicaceae, Asteraceae, Apiaceae and Artemisia. Compared to the previous layer, the Polypodiaceae decreased. These all indicate cooling in comparison with the D4 layer. The occurrence of fir (Abies), hornbeam (Carpinus) and beech (Fagus) make it possible to assume this layer was from the Subboreal period (VIII).

\section{D6-IX: Pinus - Alnus - Juniperus - Salix}

depth $0.20-0.25 \mathrm{~m}$

The decrease in alder, especially at the end of this period, and the increase in willow (Salix) and pine (Pinus) is typical for the high alluvial terraces of the Polabí lowland (Břízová 1999b, Dreslerová et al. 2004). The maximum increase was seen in Juniperus. The first occurrence of corn indicates the presence of humans in the surrounding landscape. The presence of spruce (Picea), fir (Abies), hornbeam (Carpinus) and beech (Fagus) probably indicate the Older Subatlantic period (IX) for this layer.

\section{D7-Xa: Pinus - Salix - Cyperaceae - Chenopodiaceae - (Sphagnum)}

depth $0.10-0.20 \mathrm{~m}$

A very thin layer. The low amount of palynomorpha coincides with the type of sediment (see lithology). The occurrence of wetlands is indicated by Cyperaceae and scattered willows, with Sphagnum at some sites. Pines again occur, with low but increasing amounts of birch. This layer can be dated to the older phase of the Younger Subatlantic (Xa).

\section{D8-Xb: Salix - Pinus - Betula - Alnus - (Microthyrium microscopicum)}

\section{depth $0-0.10 \mathrm{~m}$}

The last layer, probably from the younger phase of the Younger Subatlantic $(\mathrm{Xb})$, is characterized by extensive willow forests, which are again replaced by alder at the end of this period. This situation is typical for other sites in the Polabí lowland (Břízová 1999b, Dreslerová et al. 2004). The occurrence of Juniperus and corn along with typical weeds (e.g. Apiaceae, Artemisia, Brassicaceae, Chenopodiaceae, Boraginaceae) and other plants is characteristic of sites on which humans have had a significant impact (Plantago lanceolata, Asteraceae).

Algae of the genera Botryococcus, Pediastrum, Mougeotia and some other undeterminable remains occurred throughout the whole profile, but especially along with wetland vegetation in the layers D1, D3, D4, D5, D6 and D8.

Re-deposition of palynomorphs probably from the Tertiary (Sciadopytis, Tsuga, Carya, Engelhardtia) was found in layers D1, D5, D6 and at the base of D8. Sporadic pollen grains of Juglans were found in the layers D3 and D4. Human impact was observable in the layer D5, probably of Neolithic Age.

Generally, the pollen of broadleaf trees predominate, especially alder, willow, birch, hazel and to some extent also oak, lime tree and hornbeam, rarely beech. Pine was the dominant coniferous tree; spruce and fir occur sparsely or probably at long distances from the river. Juniperus occurs especially in the younger part of the profile and could be indicative of poor soils or pastures in the surroundings.

\section{Discussion}

Conditions for the fossilization of pollen and molluscan shells are quite different. The acid oxygen-free environment important for the preservation of pollen is totally unsuitable for the preservation of shells which need calcareous sediments for fossilization. Thus, the common occurrence of pollen and snails in quaternary sediments is very rare (Kovanda 1987, 1993; Břizová 1994, 1999b; Pišút et al. 2010). When it happens, however, reconstruction of the environment based on more than one group of organisms makes an interesting comparison possible.

In this paper, pollen was used to determine the stratigraphy of the Dubany profile (D) with regard to the sediment characteristics. The pollen diagram (Fig. 6) was divided into 8 LPAZ, which were also (where possible) stratigraphically classified. Two layers of the profile were dated using molluscan shells (Table 1).

Wetlands had been formed around the Dubanka stream during the Late Glacial and Early Holocene. During favourable climatic conditions, this habitat was later overgrown by alder and willow (Table 3 ). Then, an invasion of floodplain forests during the Preboreal and Boreal was documented (Table 4, Fig. 4), as has been assumed to be a general phenomenon (Ložek 2003). Sediments from the base of the profile are probably of Preboreal Age (D1). The subsequent layers (D2-D8) however, did not contain the entire sediments of individual Holocene periods because 

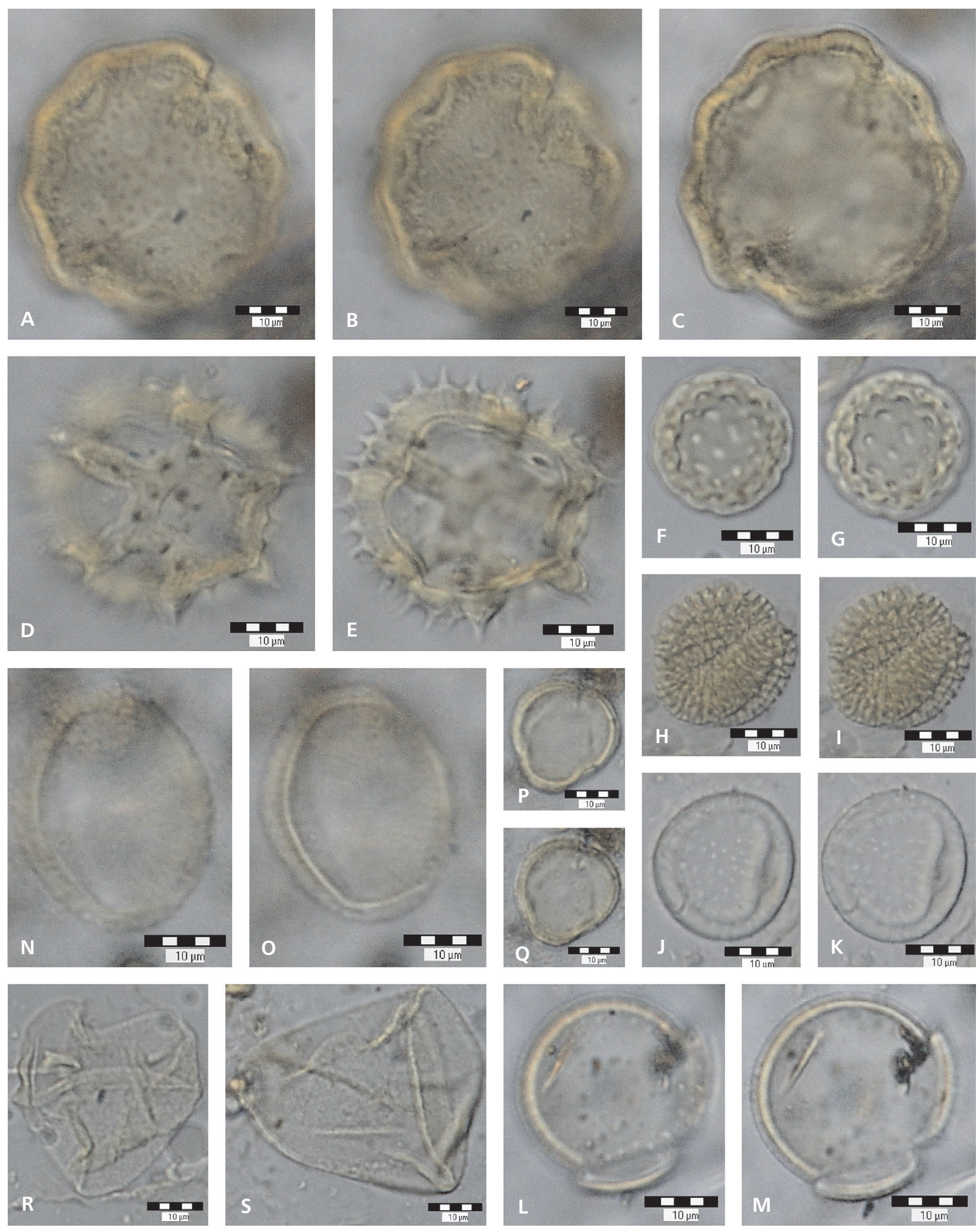

Figure 4. Palynomorphs from Dubany profile D - NAP. $\bullet$ A-C - Caryophyllaceae, depth $0.75 \mathrm{~m}$. $\bullet$ D, E - Asteraceae Liguliflorae, depth $0.75 \mathrm{~m}$. $\bullet$ F, G - Chenopodiaceae, depth $0.05 \mathrm{~m}$. $\bullet \mathrm{H}, \mathrm{I}-$ Brassicaceae, depth $0.10 \mathrm{~m}$. $\bullet \mathrm{J}-\mathrm{M}-$ Lemna cf. minor, depth 0.10, $0.75 \mathrm{~m}$. $\bullet \mathrm{N}-\mathrm{Q}-$ Artemisia, depth $0.75 \mathrm{~m} \cdot \bullet \mathrm{R}, \mathrm{S}-$ Cyperaceae, depth $0.10 \mathrm{~m}$. Scale $10 \mu \mathrm{m}$. Photo E. Bř́zová. 
Table 3. Habitat succession in the Dubany site based on pollen and molluscan analyses.

\begin{tabular}{|c|c|c|c|c|c|}
\hline Depth (m) & $\begin{array}{l}\text { LPAZ (local pollen } \\
\text { assemblage zone) }\end{array}$ & $\begin{array}{l}\text { Molluscan } \\
\text { fauna }\end{array}$ & Relative dating & $\begin{array}{c}\text { Absolute } \\
\text { dating uncal. }\end{array}$ & Prevailing habitat \\
\hline $0-0.10$ & $\mathrm{D} 8-\mathrm{Xb}$ & MF1 & $\begin{array}{l}\text { Younger Subatlantic } \\
\text { (younger phase) }\end{array}$ & & Open county (Juniperus), alder, scattered willows \\
\hline $0.10-0.20$ & D7-Xa & MF2 & $\begin{array}{l}\text { Younger Subatlantic } \\
\text { (older phase) }\end{array}$ & & Wetland, scattered woodland (willow, Betula) \\
\hline $0.20-0.25$ & D6-IX & MF3 & Older Subatlantic & $3030 \pm 40 \mathrm{BP}$ & $\begin{array}{l}\text { Woodland (willow, Pinus), open landscape (Juniperus), } \\
\text { maximum number of open country snails }\end{array}$ \\
\hline $0.25-0.40$ & D5-VIII & MF4 & Subboreal & & $\begin{array}{l}\text { Alder, woodland (Abies, Carpinus, Fagus), maximum } \\
\text { number of woodland snails }\end{array}$ \\
\hline $0.40-0.45$ & D4-VII-VIII & MF5 & Atlantic-Subboreal & $3430 \pm 30 \mathrm{BP}$ & $\begin{array}{l}\text { Alder, floodplain forest (Quercus, Tilia, Ulmus), humid } \\
\text { climate (Polypodiaceae) }\end{array}$ \\
\hline $0.45-0.50$ & D3-VI-VIII & & Atlantic-Subboreal & & Alder, willow and wetland \\
\hline $0.50-0.55$ & D2-V & & Boreal & & $\begin{array}{l}\text { Open landscape with wetlands (Cyperaceae, Poaceae) and } \\
\text { scattered pioneer woods (Betula) }\end{array}$ \\
\hline $0.55-0.75$ & D1-IV & & Preboreal & & $\begin{array}{l}\text { Open landscape (Apiaceae, Artemisia) with wetlands } \\
\text { (Sparganium/Typha) and pioneer woods (Pinus, Betula) }\end{array}$ \\
\hline
\end{tabular}

Table 4. Stratigraphic table of Holocene periods used in the text (Břízová in Dreslerová et al. 2004, Walanus \& Nalepka 2010).

\begin{tabular}{lccc}
\hline Holocene & $\begin{array}{c}\text { Modified stratigraphy by Břízová } \\
\text { (in Dreslerová } \text { et al. 2004), uncal. BP }\end{array}$ & $\begin{array}{c}\text { Modified stratigraphy by Mangerud } \\
\text { (Walanus \& Nalepka 2010), conv. BP }\end{array}$ & $\begin{array}{c}\text { Modified stratigraphy by Mangerud } \\
\text { (Walanus \& Nalepka 2010), cal. BC }\end{array}$ \\
\hline SUBATLANTIC IX, X & $2,800 / 2,300-$ recent & $2,500-$ recent & $600-$ recent \\
SUBBOREAL VIII & $5,100 / 4,500-2,800 / 2,300$ & $5,000-2,500$ & $3,800-600$ \\
ATLANTIC VI, VII & $7,700-5,100 / 4,500$ & $8,000-5,000$ & $7,000-3,800$ \\
BOREAL V & $9,100-7,700$ & $9,000-8,000$ & $8,200-7,000$ \\
PREBOREAL IV & $10,250-9,100$ & $10,000-9,000$ & $9,500-8,200$ \\
\hline
\end{tabular}

the river destroyed older sediments during periods of erosion and covered them with younger material (see also Břízová 2004, 2005, 2008b; Břízová et al. 2007). This denuding and immixture of material is typical for climatic optima with higher precipitation. For this reason, the biostratigraphic classification of layers D3, D4 and D5 is unreliable. Human impact is combined with natural influences in D5 layer. Elements of a climatic optimum (Atlantic) mix together with Subboreal species in these three layers (Fig. 6), though the D5 layer generally conforms to the Subboreal based on pollen data. Similar sedimentation with a great admixture of re-deposited material was observed during the same period in lake sediments from southern Moravia (Břízová 2009). The biostratigraphical comparison with radiocarbon dating is shown in Tables 3 and 4 .

The Dubany site is situated in an area that has been settled since the Bronze Age. Although no detailed archeological research is available directly from this site to make integrated bioarcheological research at this site possible (Brown 2009), we have some archeological information from the surrounding area. The settlement density in the eastern Polabí lowland was relatively low in the Neolithic Age, but rapidly increased during the Bronze and Iron Ages (Pleiner et al. 1978, Jiráň \& Venclová 2007-2008). The western part of this area including the České Stř̌edohoři Mts and Lower Ohře River floodplain, were probably never fully forested during the Holocene (Ložek 2007, Dreslerová et al. 2004). Thus, evidence of a canopy forest with nutrient-rich trees such as lime or elm, and the presence of woodland snails sensitive to human impact in particular (Platyla polita, Cochlodina orthostoma, Ruthenica filograna, Petasina unidentata, Discus perspectivus etc.) is important. Moreover, the majority of woodland snails have become extinct in this area only recently. Although the molluscan succession comprises only part of the whole paleobotanical succession, it provides valuable information. The radiocarbon dating places these layers at

Figure 5. Palynomorphs from Dubany profile D - Fungi. • A-E - Microthyrium microscopicum, depth 0.05 m. Pteridophyta. Polypodiaceae, depth 0.45 m. Flagellata. • G-J - Dinoflagellata, depth 0.75 m. Fungi. • K, L - Ascomycetes, depth 0.75 m. Algae. • M, N - Botryococcus, depth 0.05 m. - O - Cladocera, depth 0.10 m. Scale $10 \mu \mathrm{m}(\mathrm{C}, \mathrm{F}, \mathrm{G}-\mathrm{N}), 20 \mu \mathrm{m}$ (B, D, E), $30 \mu \mathrm{m}$ (A, O). Photo E. Břízová. 
Eva Břizová \& Lucie Juřičková • Could canopy forests survive agricultural colonization in the Polabí lowland
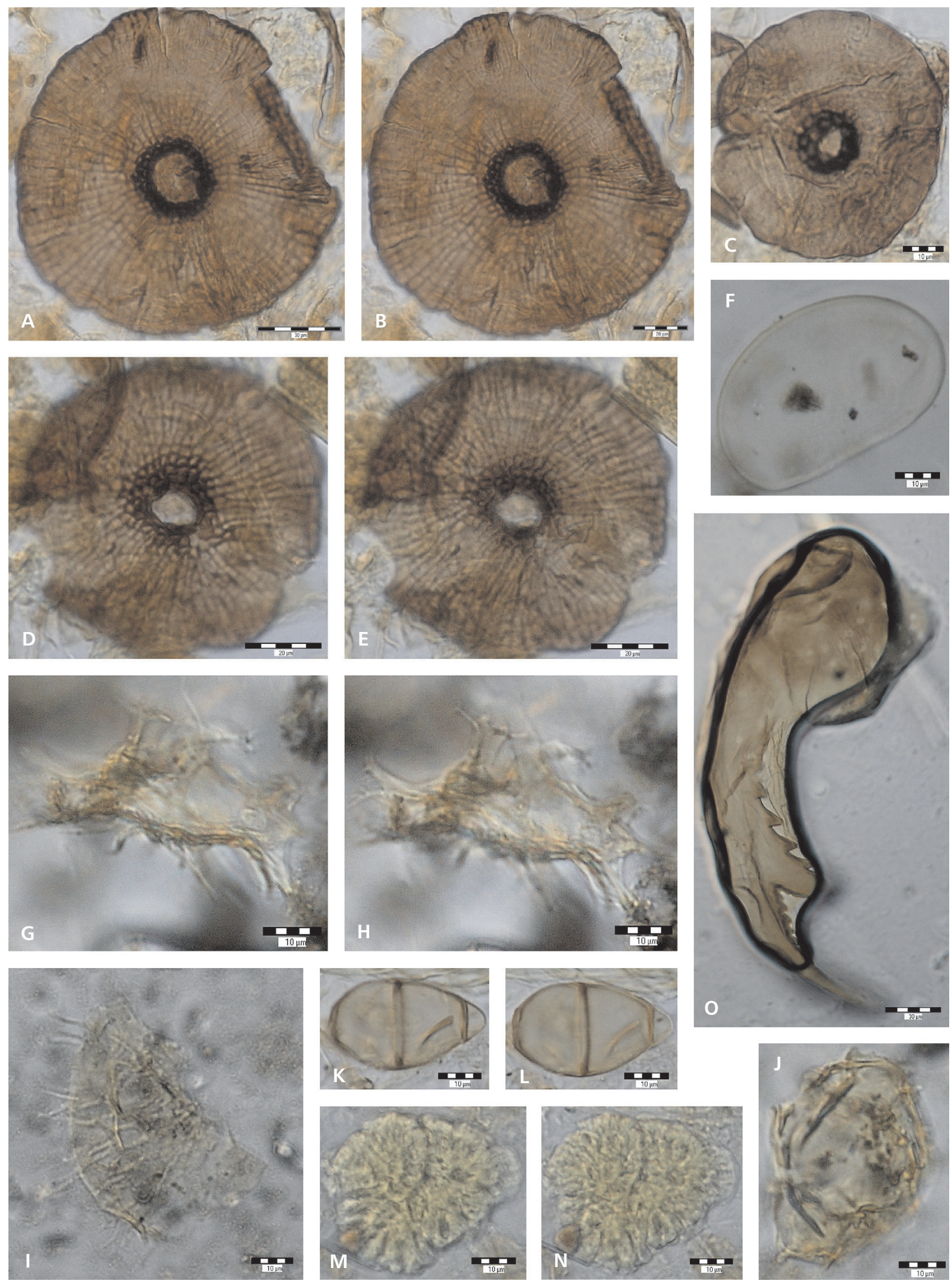


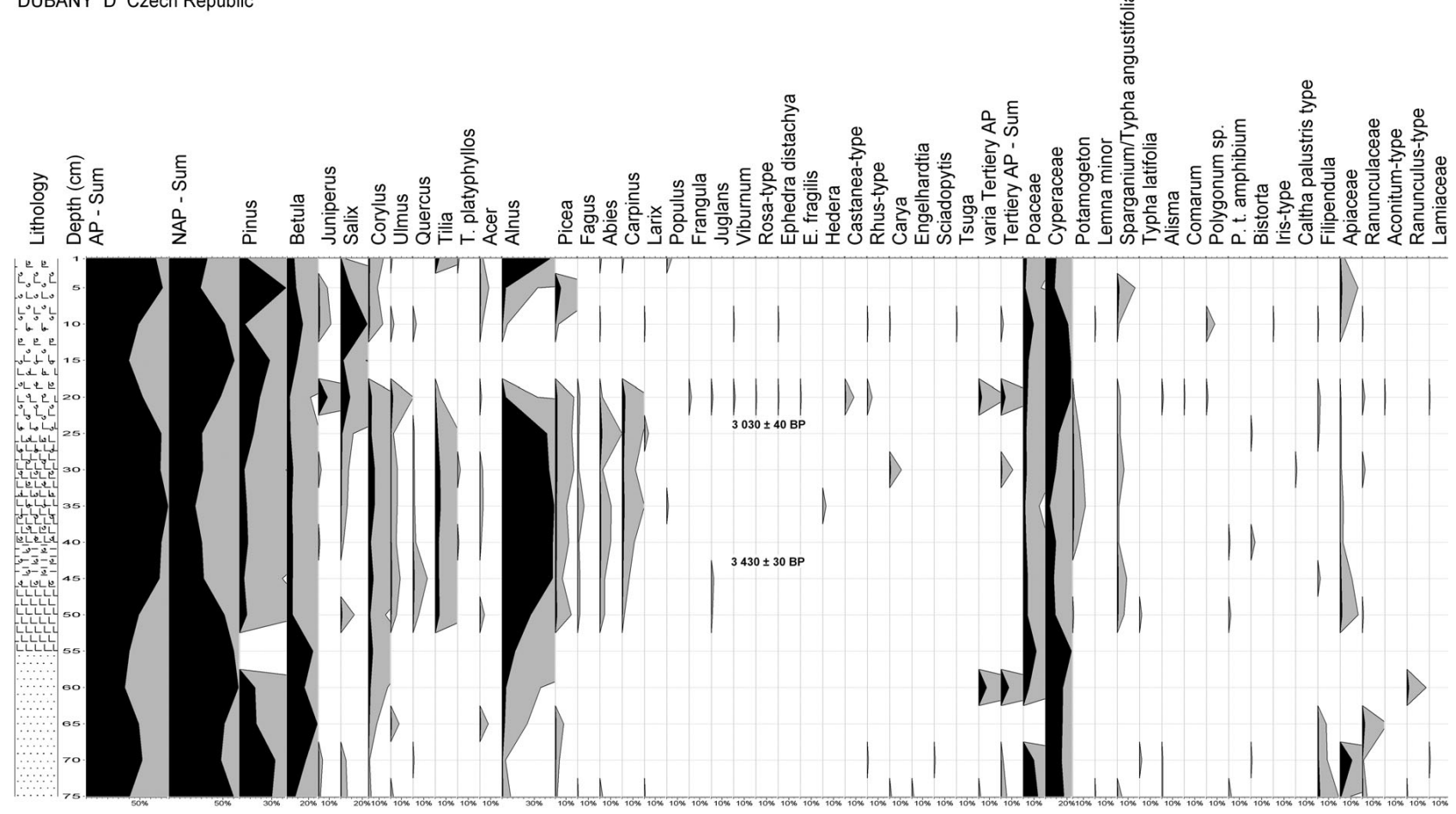

Figure 6. Pollen diagram of Dubany D (N4959`46”; E1543’32”; 233 m a.s.1.), Bohemia, the Czech Republic. Analysed by Eva Břízová. This figure continues on the opposite page.

the end of the Únětice culture (layer 5) and the Lužická culture (layer 3) of the Bronze Age (Jiráň \& Venclová 2007-2008, Table 1).

The Dubanka is a small river, with a floodplain which is more related to the regional zone rather than to the actual distance downstream (Brown et al. 1997). Thus, evidence of the canopy forest can be of local importance. However, the species composition suggests the presence of an extensive deciduous virgin forest rather than a common Central European floodplain forest (e.g. Obrdlik et al. 1995, Čejka et al. 2007). Thus, this site was functioning as a forest refuge in an agricultural landscape from at least the Bronze Age to the Subatlantic Age. On the basis of indirect evidence (e.g. mention of deer in the Polabí forests in the popular books by Prof. Julius Komárek) we even believe that the forest could have survived there until the Middle Ages or almost modern times.

The Dubany and Hurychův dolec near Vysoké Mýto (Ložek 1982, 2009) are biogeographically important sites because of the documentation of Carpathian species spreading to the west. We can compare these successions with those in the so-called Moravian Gate - a narrow depression corresponding to the Carpathian foredeep. This very important geological structure forms the border between the Czech Massif and the Western Carpathians, and is part of the water-shed between the Baltic and Black seas. The presence of Carpathian deciduous forests has been documented in several molluscan successions situated in this area (Šibrava et al. 1959; Ložek 1961a, b; Ložek \& Tyráček 1962). Carpathian species such as Macrogastra latestriata, M. tumida, Vestia turgida, Plicuteria lubomirskii, Trochulus villosulus, Monachoides vicinus or Faustina faustina together with rich mid-European woodland fauna occurred in the Moravian Gate since the Middle Holocene (Atlantic). The westward spread of these species via the so-called Třebovská Gate (a continuation of the water-shed on a Cretaceous rock substratum) during the Atlantic period has also been preliminarily documented in Hurychův dolec (Ložek 1982, 2009). However, none of the Carpathian species reach the eastern part of the Polabí lowland in Dubany. On the other hand, other woodland species could probably have seamlessly spread to this lowland.

In addition to woodland plant and snail species, the occurrence of some rare hygrophilous snail species (Vertigo angustior, V. antivertigo, Vallonia enniensis, Perpolita petronella) and plants (Polypodiaceae) indicate the presence of nutrient rich wetlands. Stagnant water and open country plants and snail species in Dubany complement a diverse landscape mosaic. Wild floodplain forests and wetlands surrounded by an agricultural landscape was probably the landscape near Pardubice during the Bronze Age. This picture sharply contrasts with the present-day monotonous open lowland. 


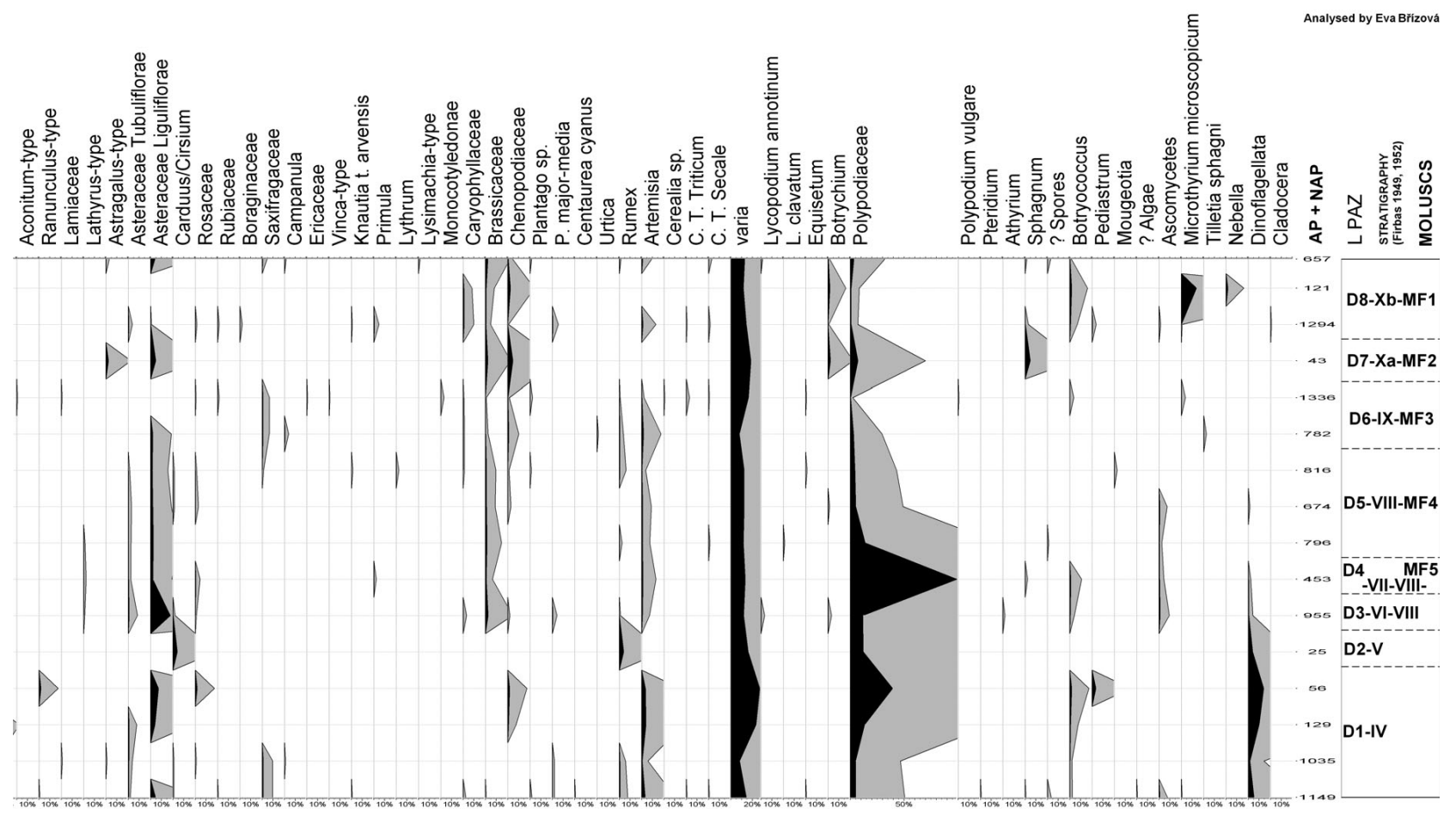

Table 5. Real amount of pollen grains and spores in individual samples from the locality of Dubany (D).

\begin{tabular}{|c|c|c|c|c|c|c|c|c|c|c|c|c|c|c|c|c|}
\hline Sample & 1 & 2 & 3 & 4 & 5 & 6 & 7 & 8 & 9 & 10 & 11 & 12 & 13 & 14 & 15 & 16 \\
\hline Depth $(\mathrm{cm})$ & 1 & 5 & 10 & 15 & 20 & 25 & 30 & 35 & 40 & 45 & 50 & 55 & 60 & 65 & 70 & 75 \\
\hline \multicolumn{17}{|l|}{ AP } \\
\hline Pinus & 50 & 52 & 66 & 12 & 252 & 101 & 35 & 44 & 61 & 18 & 65 & & 8 & 20 & 342 & 344 \\
\hline Betula & 42 & 10 & 188 & 4 & 29 & 24 & 45 & 28 & 42 & 23 & 47 & 6 & 9 & 36 & 178 & 87 \\
\hline Juniperus & & 1 & 15 & & 110 & & 2 & & 1 & & & & & & 4 & 2 \\
\hline Salix & 3 & 11 & 317 & 1 & 114 & 9 & 6 & 4 & 2 & & 12 & & & & 5 & 7 \\
\hline Corylus & 9 & 1 & 17 & & 41 & 19 & 46 & 37 & 16 & 20 & 15 & 1 & 1 & 1 & 1 & 3 \\
\hline Ulmus & 1 & & 4 & & 28 & 2 & 5 & 4 & 4 & 4 & 5 & & & 1 & & 3 \\
\hline Quercus & & & 4 & & & 1 & 1 & 1 & 2 & 6 & 5 & & & & 1 & \\
\hline Tilia & 23 & & & & 7 & 18 & 35 & 32 & 24 & 15 & 36 & & & & & \\
\hline T. platyphyllos & 1 & & & & & & 2 & & 1 & & & & & & & \\
\hline Acer & 2 & 1 & 3 & & 2 & & 2 & 2 & 1 & & 4 & & & 1 & & \\
\hline Alnus & 290 & 4 & 6 & & 44 & 324 & 354 & 326 & 374 & 212 & 253 & 3 & 2 & 3 & 3 & 9 \\
\hline Picea & & 6 & 4 & & 23 & 12 & 14 & 7 & 10 & 3 & 14 & & & 1 & 4 & 2 \\
\hline Fagus & & & & & & 1 & 1 & 4 & 1 & 1 & 2 & & & & & 1 \\
\hline Abies & 1 & & 1 & & 3 & 16 & 2 & 7 & 8 & 2 & 4 & & & & & 3 \\
\hline Carpinus & 1 & & & & 36 & 15 & 10 & 14 & 9 & 3 & 2 & & & & & \\
\hline Larix & & & 1 & & & 3 & & & & & & & & & & 1 \\
\hline Populus & 3 & & & & & & & 1 & & & & & & & & \\
\hline Frangula & & & & & 3 & & & & & & & & & & & \\
\hline Juglans & & & & & 2 & & & & & 1 & 1 & & & & & \\
\hline Viburnum & & & 1 & & 2 & & & & & & & & & & & \\
\hline Rosa-type & & & & & 1 & & & & & & & & & & & \\
\hline
\end{tabular}


Bulletin of Geosciences • Vol. 86, 2, 2011

\begin{tabular}{|c|c|c|c|c|c|c|c|c|c|c|c|c|c|c|c|c|}
\hline Sample & 1 & 2 & 3 & 4 & 5 & 6 & 7 & 8 & 9 & 10 & 11 & 12 & 13 & 14 & 15 & 16 \\
\hline Depth (cm) & 1 & 5 & 10 & 15 & 20 & 25 & 30 & 35 & 40 & 45 & 50 & 55 & 60 & 65 & 70 & 75 \\
\hline Ephedra distachya & & & 1 & & 1 & & & & & & & & & & & \\
\hline E. fragilis & & & & & 1 & & & & & & & & & & & \\
\hline Hedera & & & & & & & & 2 & & & & & & & & \\
\hline Castanea-type & & & & & 11 & & & & & & & & & & & \\
\hline Rhus-type & & & 1 & & 6 & & & & & & & & & & 1 & \\
\hline Carya & & & 1 & & & & 9 & & & & & & & & & 2 \\
\hline Engelhardtia & & & & & & & & & & & & & & & & 2 \\
\hline Sciadopytis & & & & & & & & & & & & & & & 1 & \\
\hline Tsuga & & & 1 & & & & & & & & & & & & & \\
\hline varia Tertiery AP & & & & & 37 & & & & & & & & 4 & & & 2 \\
\hline suma Tertiery AP & & & 3 & & 54 & & 9 & & & & & & 4 & & 2 & 6 \\
\hline \multicolumn{17}{|l|}{ NAP } \\
\hline Poaceae & 20 & 2 & 122 & 2 & 50 & 19 & 24 & 10 & 19 & 18 & 35 & 3 & 3 & & 101 & 154 \\
\hline Cyperaceae & 64 & 10 & 268 & 10 & 313 & 96 & 77 & 25 & 75 & 34 & 87 & 6 & 9 & 20 & 153 & 195 \\
\hline Potamogeton & & & & & 2 & 5 & 8 & 8 & 4 & & 1 & & & & & \\
\hline Lemna minor & & & 1 & & & & & & & & & & & & & 1 \\
\hline Sparganium/Typha angustifolia & & 2 & 2 & & 4 & 2 & 5 & 1 & 1 & 4 & 6 & & & & & 5 \\
\hline Typha latifolia & & & & & & & & & & & 2 & & & & 2 & \\
\hline Alisma & & & & & 2 & & & & & & & & & & 1 & 1 \\
\hline Comarum & & & & & 1 & & & & & & & & & & & \\
\hline Polygonum sp. & & & 10 & & 2 & & & & & & & & & & & \\
\hline P. t. amphibium & & & & & & & & & 1 & & 2 & & & & & 3 \\
\hline Bistorta & & & & & & 1 & & & 3 & & & & & & 1 & \\
\hline Iris-type & & & 1 & & & & & & & & & & & & & \\
\hline Caltha palustris type & & & & & & & 1 & & & & & & & & & \\
\hline Filipendula & & & 1 & & 3 & 1 & & & & 1 & & & & 1 & 9 & 22 \\
\hline Apiaceae & 3 & 2 & 8 & & 1 & 1 & 1 & 2 & 2 & 5 & 16 & & & & 114 & 11 \\
\hline Ranunculaceae & & & 1 & & 3 & & 2 & & & & 1 & & & 3 & 1 & 5 \\
\hline Aconitum-type & & & & & 1 & & & & & & & & & & & \\
\hline Ranunculus-type & & & & & & & & & & & & & 1 & & & 1 \\
\hline Lamiaceae & & & & & 1 & & & & & & & & & & 1 & \\
\hline Lathyrus-type & & & & & & & & & 1 & 1 & 1 & & & & & \\
\hline Astragalus-type & 2 & & & 1 & & & & & & & & & & & 1 & \\
\hline Asteraceae Tubuliflorae & & & 5 & & & & 1 & 2 & 2 & 1 & 8 & & & 1 & 4 & 2 \\
\hline Asteraceae Liguliflorae & 26 & & 1 & 2 & & 15 & 13 & 13 & 20 & 9 & 174 & & 4 & 5 & & 53 \\
\hline Carduus/Cirsium & & & & & & & 1 & 1 & & & 2 & 1 & & & 1 & 1 \\
\hline Rosaceae & & & 2 & & 1 & & 1 & 2 & & 2 & 1 & & 1 & & 1 & \\
\hline Rubiaceae & & & 2 & & 2 & & & & & & & & & & & 1 \\
\hline Boraginaceae & & & 3 & & & & & & & & & & & & & \\
\hline Saxifragaceae & 3 & & & & 9 & 5 & 1 & & & & & & & & 10 & 11 \\
\hline Campanula & 1 & & & & & 3 & & & & & & & & & 1 & \\
\hline Ericaceae & & & & & 1 & & & & & & & & & & & \\
\hline Vinca-type & & & & & 1 & & & & & & & & & & & \\
\hline Knautia t. arvensis & & & 1 & & & & 1 & & & & & & & & & 1 \\
\hline Primula & & & 6 & & & & & & & 1 & & & & & & \\
\hline Lythrum & & & & & & & 2 & & & & & & & & & \\
\hline
\end{tabular}


Eva Bř́zová \& Lucie Juřičková • Could canopy forests survive agricultural colonization in the Polabí lowland

\begin{tabular}{|c|c|c|c|c|c|c|c|c|c|c|c|c|c|c|c|c|}
\hline Sample & 1 & 2 & 3 & 4 & 5 & 6 & 7 & 8 & 9 & 10 & 11 & 12 & 13 & 14 & 15 & 16 \\
\hline Depth $(\mathrm{cm})$ & 1 & 5 & 10 & 15 & 20 & 25 & 30 & 35 & 40 & 45 & 50 & 55 & 60 & 65 & 70 & 75 \\
\hline Lysimachia-type & 1 & & & & & & & & & & & & & & & \\
\hline Monocotyledonae & & & & & 4 & & & & & & & & & & & \\
\hline Caryophyllaceae & & 1 & 13 & & 1 & 1 & 1 & & & & 3 & & & & & 3 \\
\hline Brassicaceae & 15 & 1 & 6 & 1 & 1 & 2 & 8 & 6 & 12 & 3 & 24 & & & & & 1 \\
\hline Chenopodiaceae & 3 & 3 & 1 & 2 & 2 & 8 & 1 & 2 & & & 2 & & 1 & 1 & & \\
\hline Plantago sp. & 1 & & & & 3 & & 1 & & & & & & & & & 2 \\
\hline P. major-media & & & 7 & & & & & & & & 4 & & & & 2 & 2 \\
\hline Centaurea cyanus & & & & & & & & & & & & & & & & 1 \\
\hline Urtica & & & & & & 1 & & & & & & & & & & \\
\hline Rumex & 1 & & & & 1 & 3 & 5 & & 2 & & 1 & 1 & & & 6 & 9 \\
\hline Artemisia & 6 & & 17 & & 3 & 14 & 3 & 6 & 6 & 6 & 7 & & 2 & 5 & 6 & 36 \\
\hline Cerealia sp. & & & & & 1 & & & & & & & & & & & \\
\hline C. T. Triticum & & & 1 & & 4 & & & & & & & & & & & 1 \\
\hline C. T. Secale & 2 & & 2 & & 1 & & & & 1 & & & & & & & 1 \\
\hline varia & 83 & 14 & 185 & 8 & 216 & 60 & 99 & 83 & 91 & 60 & 113 & 4 & 15 & 30 & 82 & 164 \\
\hline Sum AP & 426 & 86 & 628 & 17 & 702 & 545 & 560 & 513 & 556 & 308 & 465 & 10 & 20 & 63 & 538 & 462 \\
\hline Sum NAP & 231 & 35 & 665 & 26 & 634 & 237 & 256 & 161 & 240 & 145 & 490 & 15 & 36 & 66 & 497 & 687 \\
\hline $\mathrm{AP}+\mathrm{NAP}=100 \%$ & 657 & 121 & 1293 & 43 & 1336 & 782 & 816 & 674 & 796 & 453 & 955 & 25 & 56 & 129 & 1035 & 1149 \\
\hline \multicolumn{17}{|l|}{ PTERIDOPHYTA } \\
\hline Lycopodium annotinum & 1 & & & & & & & & & & 3 & & & & & \\
\hline L. clavatum & & & & & & & & & 1 & & & & & & & \\
\hline Equisetum & & & & & 1 & & 1 & & & & & & & & & 1 \\
\hline Botrychium & 1 & 2 & 1 & 1 & & & & 1 & & & 3 & & & & & \\
\hline Polypodiaceae & 21 & 1 & 9 & 3 & 3 & 23 & 35 & 33 & 109 & 448 & 111 & 3 & 22 & 17 & 48 & 58 \\
\hline Polypodium vulgare & & & & & 1 & & & & & & & & & & & \\
\hline Pteridium & & & & & & & & & & & & & & & & 1 \\
\hline Athyrium & & & & & & & & & & & 2 & & & & & \\
\hline \multicolumn{17}{|l|}{ BRYOPHYTA } \\
\hline Sphagnum & 1 & & 4 & 2 & & & & & & 1 & & & & & & 1 \\
\hline ?Spores & 2 & & & & & & & & 1 & & & & & & & 4 \\
\hline Sum of spores & 26 & 3 & 14 & 6 & 5 & 23 & 36 & 34 & 111 & 449 & 119 & 3 & 22 & 17 & 48 & 66 \\
\hline \multicolumn{17}{|l|}{ ALGAE } \\
\hline Botryococcus & 1 & 2 & 9 & & 5 & & & & & 5 & 4 & & 1 & 1 & 2 & 3 \\
\hline Pediastrum & & & 5 & & & & & & & & & & 2 & & & \\
\hline Mougeotia & & & & & & & 2 & & & & & & & & & \\
\hline ?Algae & & & & & & & & & & & & & & & & 1 \\
\hline \multicolumn{17}{|l|}{ FUNGI } \\
\hline Ascomycetes & & & 2 & & & & & 5 & 2 & 2 & 9 & & & & & 9 \\
\hline Microthyrium microscopicum & & 17 & 1 & & 5 & & & & & & & & & & & 1 \\
\hline Tilletia sphagni & & & & & & 2 & & & & & & & & & & \\
\hline \multicolumn{17}{|l|}{ RHIZOPODA } \\
\hline Nebella & & 2 & & & & & & & & & & & & & & \\
\hline \multicolumn{17}{|l|}{ FLAGELLATA } \\
\hline Dinoflagellata & & & & & & & & 1 & & 1 & 4 & 1 & 8 & 13 & 15 & 59 \\
\hline CLADOCERA & & & 1 & & & & & & & & & & & & & \\
\hline
\end{tabular}




\section{Acknowledgements}

The paleobotanical research reported here was supported by the research project of the Czech Geological Survey, Prague, MZP000257801, project IGCP 518 and internal projects (326500, 548007). The malacological research was supported by the Grant Agency of the Czech Republic, P504/10/0688, and MSMT project 0021620828. We are grateful to our colleague Jiří Kovanda, without his help this paper would not exist. We would also like to thank Michal Horsák for the determination of Pisidium specimens. We are also grateful to the referees Vojen Ložek and Václav Cílek for their valuable comments on the manuscript. We thank to David Hardekopf for the English revision.

\section{References}

Adamová, M., BŘízová, E., Havlíček, P. \& Holásek, O. 2008. Kvartérní sedimenty v okolí Lysé nad Labem a jejich geochemické složení (Quaternary sediments in the surroundings of Lysá nad Labem and their geochemical composition). Zprávy o geologických výzkumech v roce 2007, 85-89.

AleXANDRowitZ, S.W. 1987. Malacological analyses in Quaternary research. Kwartalnik Akademii górniczo-hutniczej im. Stanislava Staszica, Geologia 13, 1-240. [in Polish, English summary]

BABOR, J.F. 1901. Měkkýši českého plistocaenu a holocaenu. Archiv pro přirodovědecké prozkoumání Čech 11(5), 1-83.

Boothroyd, J.C. \& Nummedal, D. 1978. Proglacial braided outwash: a model for humid alluvial-fan deposits, 641-668. In Miall, A.D. (ed.) Fluvial sedimentology. Canadian Society of Petroleum Geologists, Memoir 5.

Bridge, J.S. 2003. Rivers and Floodplains. 491 pp. Blackwell Publishers, Bodmin, Cornwall.

Bridgland, D. \& Westaway, R. 2007. Climatically controlled river terrace staircases: A worldwide Quaternary phenomenon. Geomorphology 98(3-4), 285-315. DOI 10.1016/j.geomorph.2006.12.032

BŘízovÁ, E. 1994. Pollen analyses of the Kobeřice creek alluvial deposits, 100-103. In RÚŽıčKovÁ, E. \& Zeman, A. (eds) Holocene flood-plain of the Labe-River. Contemporary state of research in Czech Republic. Geological Institute ASCR, Prague.

BŘizovÁ, E. 1999a. Late Glacial and Holocene development of the vegetation in the Labe (Elbe) River flood-plain (Central Bohemia, Czech Republic). Acta Paleobotanica, Supplement 2 - Proceedings $5^{\text {th }}$ EPPC, 549-554.

BŘízovÁ, E. 1999b. Počátky pozdněglaciální a holocénní vegetace u Rynholce (Late Glacial and Holocene Vegetation near Rynholec), 27-34, 211, 225. In KoLBeK, J. et al. Vegetace Chráněné krajinné oblasti a Biosférické rezervace Křivoklátsko. 1. Vývoj krajiny a vegetace, vodní, pobřežní a luční společenstva (Vegetation of the Protected Landscape Area and Biosphere Reserve Křvoklátsko 1. Development of the Landscape and Vegetation, Aquatic, River Bank and Meadow Communities). 232 pp. AOPK ČR a Botanický ústav AV ČR Průhonice, Prague.
BŘízovÁ, E. 2001. Výzkum nivy řeky Moravy a jeho význam pro studium povodní (Research of the Morava River floodplain and its importance for study of floods). Zprávy o geologických výzkumech v roce $2000,61-62$.

BŘízovÁ, E. 2004. Vývoj krajiny v českém středním Polabí v pozdním glaciálu a holocénu [Late Glacial and Holocene development of vegetation in the Labe River floodplain (Central Bohemia, Czech Republic)], 12-21. In MĚKotovÁ, J. \& ŠTĚRBA, O. (eds) Řični krajina se zaměrením na problematiku řek a okolní krajiny. Sborník př́spěvků z 2. ročníku pracovni konference (River Landscape, proceedings of conference). Olomouc.

BŘízovÁ, E. 2005. Hodnocení ekologické stability nivy Labe v pozdním glaciálu a holocénu (Valorization of ecological stability of the Labe River floodplain during Late Glacial and Holocene - pollen analysis), 16-25. In MĚKOTOVÁ, J. \& ŠTĚRBA, O. (eds) Říčni krajina 3, sborník př́spěvků z konference. Olomouc.

BŘízovÁ, E. 2007. Vodní a mokřadní ekosystémy v průběhu pozdního glaciálu a holocénu na základě pylových analýz (Aquatic and wetland ecosystems during the Late Glacial and Holocene based on pollen analyses). Zprávy České botanické společnosti, Materiály 42(22), 85-97.

BŘízovÁ, E. 2008a. Paleoekologický vývoj niv během pozdního glaciálu a holocénu ve střední Evropě, 11-19. In PitHaRT, D., Benedová, Z. \& KřovÁKovÁ, K. (eds) Ekosystémové služby řččni nivy. Ústav systémové biologie a ekologie AV ČR, v.v.i., Vodní hospodářství, Třeboň.

BŘízovÁ, E. 2008b. Reconstruction of vegetation development on the floodplain of the Litavka River in the Holocene (Central Bohemia, Brdy Mts.). Acta Musei nationalis Pragae, Series $B$ - historia naturalis 64(2-4), 173-184.

BŘízovÁ, E. 2009. Quaternary environmental history of the Čejčské jezero (S. Moravia, Czech Republic). Bulletin of Geosciences 84(4), 637-652. DOI 10.3140/bull.geosci.1140

BŘízová, E., HavlíčeK, P. \& VACHeK, M. 2001. Výzkum organických sedimentů na jižní Moravě (Research of the organic sediments in the South Moravia). Zprávy o geologických výzkumech v roce 2001, 67-69.

BŘízová, E., Havlíček, P., Novák, Z. \& Petrová, P. 2000. Kvartérní sedimenty na listu Vracov 34-222 a Strážnice 34-223 (Quaternary sediments on streets Vracov 34-222 and Strážnice). Zprávy o geologických výzkumech $v$ roce 1999, 14-17.

BŘízová, E., PIŠút, P., ČEJKA, T. \& UherČíKovÁ, E. 2007. Holocenní vývoj nivy Dudváhu (lokalita Štúrová, Žitný ostrov, Slovensko) [Holocene development of the Dudváh River floodplain (locality Štúrová, Žitný ostrov Island, Slovakia)], 22-36. In MĚKotová, J. \& ŠTĚrba, O. (eds) Řiční krajina 5, recenzovaný sborník př́spěvků z konference. Olomouc.

BŘízovÁ, E., PIšút, P. \& UhERČííovÁ, E. 2007. Rekonstrukce vývoje lesní vegetace na Žitném ostrově na základě pylové analýzy (Reconstruction of the forest vegetation development in the Žitný ostrov Island on the basis of pollen analysis), 209-215. In KrIŽová, E. \& UjHÁZY, K. (eds) Dynamika, stabilita a diverzita lesných ekosystémov. TU vo Zvolene, Zvolen. 
Bronk RAMSEY, C. 2009. Baetsian analysis of radiocarbon dates. Radiocarbon 51(1), 337-360.

Brown, A.G. 2009. Collucial and alluvial response to land use change in Midland England: An integrated geoarcheological approach. Geomorphology 108, 92-106.

DOI 10.1016/j.geomorph.2007.12.021

Brown, A.G., Harper, D. \& Peterken, G.F. 1997. European floodplain forests: structure, functioning and management. Global Ecology and Biogeography Letters 6, 169-178. DOI 10.2307/2997730

ČEJKa, T., Horsák, M. \& NéMETHOVÁ, D. 2007. The composition and richness of Danubian floodplain forest faunas in relation to forest type and flood frequency. Journal of Molluscan Studies 74(1), 37-45.

Dreslerová, D., BŘízovÁ, E., RưŽIČKovÁ, E. \& Zeman, A. 2004. Holocene environmental processes and alluvial archaeology in the middle Labe (Elbe) valley, 121-171. In GojdA, M. (ed.) Ancient landscape, settlement dynamics and non-destructive archaeology. Academia, Praha.

ERdtman, G. 1943. An introduction to pollen analysis. 712 pp. Academic Press, New York.

ERdtMAn, G. 1954. An introduction to polen analysis. 238 pp. Chronica Botanica, Waltham, Mass.

FAEGRI, K. \& IVERSEN, J. 1964. Textbook of pollen analysis. 347 pp. Scandinavian University Books, Copenhagen.

FIRBAS, F. 1949, 1952. Spät- und nacheiszeitliche Waldgeschichte Mitteleuropas nördlich der Alpen. I. - 480 pp., II. - 256 pp. Gustav Fischer Verlag, Jena.

Frankenberger, Z. 1913. Příspěvky k známostem o evropských Clausiliích. Sborník Klubu př́rodovědeckého v Praze 1912(12), 1-10.

HejnÝ, S. \& Slavík, B. (eds) 1988. Květena České socialistické republiky 1 (Flora of the Czech Socialist Republic 1). 560 pp. Academia, Praha.

HejnÝ, S. \& Slavík, B. (eds) 1990-1992. Květena České republiky 2, 3 (Flora of the Czech Republic 2, 3). 2 - 544 pp., 3 542 pp. Academia, Praha.

HLAVÁč, V.F. 1937. Topografický soupis čsl. měkkýšů recentních a kvartérních I. 52 pp. Publikace Hlaváčova přirodovědeckého musea, Lázně Bělohrad.

Hradecká, L., Břízová, E., Havlíček, P. \& Svobodová, M. 2008. Mikropaleontologický výzkum svrchně pleistocénních sedimentů $\mathrm{v}$ pískovně u Pístů. Zprávy o geologických výzkumech $v$ roce $2007,120-123$.

JANKOVSKÁ, V. 2008. Niva v čase a prostoru: poznatky ze středoevropské paleoekologie a analogie ze současného ruského severu, 96-100. In Pithart, D., Benedová, Z. \& KR̆OVÁKovÁ, K. (eds) Ekosystémové služby říčni nivy. Ústav systémové biologie a ekologie AVČR, Třeboň.

JiRÁñ, L. \& VenclovÁ, N. (eds) 2007-2008. Archeologie pravěkých Čech 1-8. Archeologický ústav AV ČR, v.v.i. Praha.

KALICKI, T. 2006. Zapis zmian klimatu oraz działalności człowieka $i$ ich rola $w$ holoceńskiej ewolucji dolin środkowoeuropejskich. 348 pp. Polska Akademia Nauk, Instytut Geografii i Przestrzennego Zagospodarowania im. Stanisława Leszczyckiego, Warszawa.
Kovanda, J. 1971. Kvartérní vápence Československa. Sborník geologických věd, Antropozoikum A 7, 1-236.

KovandA, J. 1983. Holozäne Süsswasserkalke und ihre Bedeutung für die Gliederung der Flussablagerungen in der Tschechoslowakei. Geologisches Jahrbuch A 71, 285-289.

KovandA, J. 1987. Postglaciál u Kobeřic na severní Moravě. Věstník Ústředního ústavu geologického 62(3), 143-155.

Kovanda, J. 1993. O slatinách u Rynholce, profilu svahovin v Karlštejně a o svahových sériích ze Stranzendorfu a Krems-střelnice (Dolní Rakousko). Zprávy o geologických výzkumech v roce 1992, 57-58.

KubÁt, K., Hrouda, L., Chrtek, J. JR., Kaplan, Z., Kirschner, J. \& ŠTĔPÁNEK, J. (eds) 2002. Klíč ke květeně České republiky (Key to flora of the Czech Republic). 928 pp. Academia, Praha.

LožEK, V. 1961a. Stratigrafický výzkum travertinu u Skřečoně. Antropozoikum 9(1959), 35-45.

LOŽEK,V. 1961b. Stratigrafický výzkum ložiska sypkých sintrů a slatin u Dluhonic na Přerovsku. Antropozoikum 9(1959), 65-76.

LožEK, V. 1964. Quartärmollusken der Tschechoslowakei. Rozpravy Ústředního ústavu geologického 31, 1-374.

LOŽEK, V. 1982. Faunengeschichtliche Grundlinien zur spät- und nacheiszeitlichen Entwicklungder Molluskenbestände in Mitteleuropa. Rozpravy Československé akademie věd, $\check{R} a d a$ matematických a přirodních věd 92(4), 1-106.

LožEK, V. 2000. Palaeoecology of Quaternary Mollusca. Antropozoikum 24, 35-59.

LožEK, V. 2003. Naše nivy v proměnách času. I. Vznik a vývoj dnešních niv. Ochrana př́rody 58(4), 101-106.

LOŽEK, V. 2007. Zrcadlo minulosti. Česká a slovenská krajina v kvartéru. 198 pp. Dokořán, Praha.

LožEK, V. 2009. Refúgia, migrace a brány II. Živa 5, 194-198.

LOŽEK, V. \& TYRÁČEK, J. 1960. Die holozänen Travertine von Bernatice an der Oder. Antropozoikum 10(1960), 171-188.

Obrdlik, P., FAlkner, G. \& CAStella, E. 1995. Biodiversity of Gastropoda in European floodplains. Archiv für Hydrobiologie, Supplement 101, 339-356.

Overbeck, F. 1958. Pollenanalyse quartärer Bildungen, 325-410. In FREUND, H. (ed.) Handbuch der Mikroskopie in der Technik. Umschau Verlag, Frankfurt am Main.

Petrbok, J. 1916. Př́íspěvek k seznání holocaenních měkkýšů v Čechách. Rozpravy České akademie císaře Františka Josefa pro vědy, slovesnost a umění, Třída II (mathematicko-přirodnická) 25(20), 1-15.

Petrbok, J. 1951. Monografická studie českých měkkýšů rodu Monacha, Isognomostoma, Helicodonta, Euomphalia, Petasia, Campylea, Chilotrema a Perforatella. Rozpravy České akademie věd a umění, Tř́ida II (matematicko-přirodovědecká) 60(28), 1-37.

PIšút, P., BŘízovÁ, E., ČEJKA, T. \& PIPÍK, R. 2010. Paleofloristic and paleofaunistic analysis of Dudváh River oxbow and its implication for Late Holocene palaeoenvironmental development of the Žitný ostrov Island (SW Slovakia). Geologica Carpathica 61(6), 513-533.

Pleiner, R. (ed.) 1978. Pravěké dějiny Čech. 872 pp. Academia, Praha. 
Slavík, B. (ed.) 1995-2000. Květena České republiky 4, 5, 6 (Flora of the Czech Republic 4, 5, 6). 4-532 pp., 5 - 568 pp., $6-770$ pp. Academia, Praha.

Slavík, B. \& ŠTĚPÁnKovÁ, J. (eds) 2004. Květena České republiky 7 (Flora of the Czech Republic 7). 767 pp. Academia, Praha.

Šibrava, V., Macoun, J., Pokorný, M., Holánek, F., Tyráček, J. \& LožEK, V. 1959. Zpráva o výzkumu a mapování čtvrtohorních pokryvných útvarů Ostravska a Moravské Brány za r. 1957. Antropozoikum 8(1958), 253-278.

ŠTĚPÁnKovÁ, J., ChrteK, J. JR. \& KaPlan, Z. (eds) 2010. Květena České republiky 8(Flora of the Czech Republic 8). 712 pp. Academia, Praha.
TyRÁČEK, J. 2001. Upper Cenozoic fluvial history in the Bohemian Massif. Quaternary International 79, 37-53. DOI 10.1016/S1040-6182(00)00121-X

VoLŠAN, V. 1969. Zpráva o základním výzkumu a geologickém mapování kvartéru na listu Pardubice a o revizi křídových makrofosilií na listu Holice. Zprávy o geologických výzkumech $v$ roce 1967, 266-268.

Walanus, A. \& NalePKa, D. 1999. POLPAL. Program for counting pollen grains, diagrams plotting and numerical analysis. Acta Paleobotanica, Supplement 2, 659-661.

Walanus, A. \& NALEPKA, D. 2010. Calibration of Mangerud's boundaries. Radiocarbon 52(4), 1639-1644. 